International Journal of Current Microbiology and Applied Sciences

ISSN: 2319-7706 Volume 6 Number 2 (2017) pp. 809-816

Journal homepage: http://www.ijcmas.com

Original Research Article

http://dx.doi.org/10.20546/ijcmas.2017.602.090

\title{
Detection of Human Bocavirus in Egyptian Children Suffering from Acute Lower Respiratory Tract Infection
}

\author{
Ghada E. Amr ${ }^{1}$, Dina M. Atef ${ }^{1}$ and Rabab Elbehedy ${ }^{2}$ \\ ${ }^{1}$ Departments of Clinical Pathology, Faculty of Medicine, Zagazig University, Egypt \\ ${ }^{2}$ Pediatrics, Faculty of Medicine, Zagazig University, Egypt \\ *Corresponding author
}

\section{A B S T R A C T}

\begin{tabular}{|l|}
\hline Key w or d s \\
Human bocavirus, \\
Lower respiratory \\
tract infection in \\
children, Real-time \\
PCR, Serology.
\end{tabular}

Human bocavirus (HBoV) was first identified as parvovirus in 2005 in nasopharyngeal aspirates of children with lower respiratory tract infection. The objectives of this study were to determine $\mathrm{HBoV}$ as a cause of acute lower respiratory tract infection(ALRTI) in children by investigating the presence of HBoV DNA, to evaluate diagnostic efficiency of HBov IgM assay in the serum of the studied patients and to assess the impact of the viral load on the clinical manifestations of children with positive HBoV DNA samples. We investigated 123-nasopharyngeal aspirate samples of hospitalized children with ALRTI by Real-time PCR for detection of HBoV DNA and estimating its viral load. Estimation of immunoglobulin M (IgM) by ELISA in patient's serum samples was another method used for diagnosis of $\mathrm{HBoV}$ infection. There were 19 patients with positive nasopharyngeal aspirate samples by PCR among them there were 16 serum samples positive for $\mathrm{HBoV}$ IgM by ELISA (sensitivity was $84.2 \%$ ). Longer hospital stay and severe ALRTI signs were detected in children samples with high viral load (16 samples).

\section{Introduction}

Acute respiratory tract infection is a leading cause of significant morbidity worldwide. It is one of the most important causes of mortality in infants and young children and disabilityadjusted life years lost in developing countries (WHO 2009). Although some viruses, such as influenza virus, respiratory syncytial virus and human adenovirus are responsible for most acute respiratory tract infection, however, some etiological causes remain unknown (Pavia 2011).

Human bocavirus 1 (HBoV-1) was first identified in 2005and defined as DNA virus belongs to the Parvoviridae family that has been frequently detected in young children experiencing acute respiratory tract illness (Allander et al., 2005). Three other bocaviruses, HBoV2, 3, and 4, were detected in human Feces (Kapoor et al., 2009), and HBoV2 has been associated with acute gastroenteritis (Arthur et al., 2009). The role of $\mathrm{HBoV}$ as the single causative agent for respiratory tract infections remains unclear; few studies were carried out in Egypt to estimate the role of this virus in ALRI in children. The infection by HBoV1 can be diagnosed by many techniques that include serology and PCR amplification of viral nucleic acid, which is the most common 
technique used for the detection of HBoV1 in respiratory samples (Bruning et al., 2016). The aim of this work was to investigate the role of $\mathrm{HBoV}$ as a cause of acute lower respiratory tract infection (ALRTI) in children. We used real- time PCR for detection of HBoV DNA in nasopharyngeal aspirate (NPA) samples and we also investigated the diagnostic efficiency of HBoV IgM detection in patient's serum. Investigation of the relation between different viral load and the clinical characteristics of the children with ALRTI was another goal of this study.

\section{Materials and Methods}

A total of 123 children less than 60 months (5years) of age with a clinical and radiological diagnosis of ALRTI in Children's Hospital of Zagazig University from May 2015 to April 2016 were enrolled in this study. All the investigations were performed following the relevant guidelines and regulations of Zagazig University. The methods were carried out in accordance with the approved guidelines. The parents of all study participants gave written informed consent before study enrollment.

The patients were suffered from acute lower respiratory tract infection with onset during the previous seven days requiring hospitalization that included either history of fever and/or current fever $\geq 38^{\circ} \mathrm{C}$ or current hypothermia $<35.5^{\circ} \mathrm{C}$ and at least one of abnormal breath sounds, tachypnea (according to age), chest wheeze, cough, or respiratory distress (nasal flaring, chest in drawing, grunting).Clinical implication of HBov infection was assessed by clinical symptoms and length of hospital stay.

\section{Specimens}

Approximately $2 \mathrm{ml}$ nasopharyngeal aspirates (NPA) samples were obtained from all patients within 24 hours of admission. For HBoV-IgM detection by ELISA, $3 \mathrm{ml}$ of blood was withdrawn from patients and the serum samples were separated.

For diagnosis of bacterial infection, NPA specimens were inoculated on MacConkey agar, blood agar and chocolate agar plates that incubated in aerobic, $\mathrm{CO}_{2}$ condition at $37^{\circ} \mathrm{C}$ for 24-48 hours. Matrix-assisted laser desorption ionization-time of flight mass spectrometry (MALDI-TOF MS) was used to identify bacterial isolates. Another part of the specimens was stored in aliquots at $-80^{\circ} \mathrm{C}$ for PCR. Serum samples were separated and stored at $-20^{\circ} \mathrm{C}$ for $\mathrm{HBoV}$-IgM antibodies detection.

\section{Real-time PCR}

The total nucleic acids were extracted from the NPA samples using QIAamp MinElute virus spin DNA/RNA extraction kit (Qiagen, USA) following the manufacturer's instructions. Briefly, $200 \mu \mathrm{L}$ of sample was extracted and the nucleic acids were eluted in 20-150 $\mu \mathrm{L}$ of eluted buffer and stored at $80^{\circ} \mathrm{C}$.

The presence of human bocavirus genomes were detected from the extracted nucleic acid by real-time quantitative polymerase chain reaction (PCR) with commercial $\mathrm{HBoV}$ realtime kit (The Primer design ${ }^{\mathrm{TM}}$ genesig® Human bocavirus viral protein gene advanced kit) according to the manufacturer's instructions using Stratagene Mx3005P qPCR instrument (Agilent Technologies, USA).

A total reaction mix for each DNA sample prepared was $20 \mu \mathrm{l}$ consisting of $10 \mu \mathrm{l}$ of

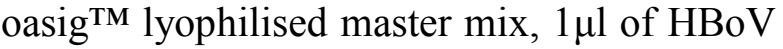
primer/probe mix, $1 \mu 1$ of Internal extraction control primer/probe mix, $3 \mu \mathrm{l}$ RNAse/DNAse free water and $5 \mu \mathrm{l}$ of extracted DNA template. The PCR amplification thermal cycling conditions were as the following: 15 
min at $37^{\circ} \mathrm{C}$, enzyme activation step of $2 \mathrm{~min}$ at $95^{\circ} \mathrm{C}$ and 50 cycles consist of: denaturation step was $10 \mathrm{sec}$ at $95^{\circ} \mathrm{C}$ and annealing/elongation step of $1 \mathrm{~min}$ at $60^{\circ} \mathrm{C}$. To avoid cross-contamination of the reaction, negative control $(5 \mu \mathrm{l}$ of RNAse/DNAse free water instead to DNA template) and 6 serial dilutions of the positive control that had been provided in the kit, were included in each PCR assay. The fluorescent signal from the FAM channel was measured against the signal from VIC channels, in order to normalize the non-PCR-related fluorescence fluctuations between samples. A standard curve of amplification was produced using serial dilutions of a positive control; the quantitative calculation of the viral loads from the cycle threshold $(\mathrm{Ct})$ was performed according to the standard curve (copies/ml).

\section{Serology}

HBoV-IgM antibody levels were determined by enzyme-linked immunosorbent assay (ELISA) supplied by NOVA (Beijing, China) in all patients' serum samples according to the manufacturer's instructions. The absorbance was read at $450 \mathrm{~nm}$. The average of negative and positive controls results were $\leq 0.10$ and $\geq 1.00$ respectively, the calculating critical (cut off) was the average of negative control + 0.15

\section{Statistical analysis}

The data was analyzed using SPSS statistical package software computer program version 17 (SPSS Inc., Chicago, IL). Shapiro - Wilk test was used to verify the normality of distribution of continuous variables. Data were expressed as a number of percentages, mean or median as appropriate. Categorical data were analyzed using the Chi- square test and Fisher's exact and numerical data are analyzed by Mann-Whitney U Tests. Receiver operating characteristic (ROC) curve was used to calculate cut off of high viral load.
Statistical significance for all the tests was set at a P-value of less than $0.05(<0.05)$. Sensitivity, specificity, PPV and NPV was calculated to evaluate the diagnostic efficiency of $\mathrm{HBoV}$ detection.

\section{Results and Discussion}

The mean age of the children included in this study was 37 months. The clinical finding and epidemiological characteristics of patients with HBoV DNA positive samples by realtime are illustrated in table 1 . The detection of $\mathrm{HBoV}$ was in its peak by age range from 6 to 12 months (Figure 1) and its incidence was highest in winter in comparison to other seasons (Figure 2).

This study showed that among 123 NPA samples obtained from children with ALRI there were 19 positive results for $\mathrm{HBoV}$ DNA by real-time PCR technique $(15.4 \%)$. There were 16 positive serum samples for $\mathrm{HBoV}$ IgM by ELISA (13\%), all these samples also belonged to patients who had positive PCR results (16/19) (84.2\%), and there were three patients with $\mathrm{HBoV}$ DNA positive PCR results and negative $\mathrm{HBoV}$ IgM. The sensitivity and specificity, PPV and NPV of ELISA are illustrated in table 2.

According to the positive results of $\mathrm{HBoV}$ DNA by real-time PCR we divided the results into high and low viral load groups, $1.0 \times 10^{4}$ copies $/ \mathrm{mL}$ was the cutoff value that was calculated using ROC curve. There were 13 samples with high viral load and 6 samples with low viral load values. There was a significant association between high viral load estimated by real-time PCR and increase the length of hospital stay, a presence of dyspnea, wheeze and tachycardia, while there was no significant association between the values of viral load and the presence of other clinical signs (Table 3). There was bacterial coinfection in three $\mathrm{HBoV}$ positive NPA samples that were Streptococcus pneumoniae, 
$S$. aureus and E. coli, all these samples were accompanied by a low viral load.

Human bocavirus has been described as an etiological agent of respiratory virus infections since 2005; however, there was a lack of information about the role of this pathogen in the etiology of acute lower respiratory infections among the Egyptian children. We determined the incidence of HBoV by real-time PCR and serology in children suffering from ALRI and investigated the clinical significance of different viral load of this virus.

Our results showed that the detection rate of HBoV DNA from NPA samples of children with ALRI was $15.4 \%$, that was in agreement with the results reported by Symekher et al., (2013) that was(16.8\%)also it was in agreement with other studies which have had a detection range of between $1.5 \%-19 \%$ (Allander et al., 2007,Silva2010,AlRousan2011) and with another study by Dunn and Miller (2014)that reported, HBoV can be detected to in 1.6 to $21.5 \%$ of children with symptoms of respiratory tract infection.

However, our results were lower than the results of two previous studies in Egypt by Abdel-Moneim et al., (2016), Zaghloul (2011)who reported that $\mathrm{HBoV}$ was found in $56.8 \%$ and $24.5 \%$ respectively in the examined children in their studies, also our result was lower than that reported by Denge et al., (2012) that was $22 \%$ and higher than those reported by Weissbrich et al., (2006) and Neske et al., (2007) who had found HBoV DNA by PCR techniques in NPA samples were $10.3 \%, 12 \%$ respectively. This variation may be due to different age groups of patients, different methods of detection of the virus.

In the current study, the detection rate of $\mathrm{HBoV}$ infection was at its peak between the ages of 6 and 12 months (57.9\%). Our results was in agreement with Jiang et al., (2016) who reported that the infections almost completely confine to infants and young children also in agreement with most of the previous studies by Allender et al., (2005), Choi et al., (2006), Chow et al., (2009) and Abdel-Moneim et al., (2013). However, some authors reported that $\mathrm{HBoV}$ is also a frequent virus in adults with respiratory disease Guido et al., (2012) and Ghietto et al., (2012).

In this study all $\mathrm{HBoV}$ positive cases occurred during late fall and winter, this finding is consistent with same findings by other authors Allander et al., (2005), (Weissbrich et al., (2006), Chow et al., (2008) and Martin et al., (2010).

Real-time PCR has been used as an indicator of the degree of active viral infection, interactions between the virus and the host, and the role of viral reactivation or persistence in the progression of disease (Mackay 2004). Our results showed that there were significant statistical differences between patients with high-viral-load and low-viral-load groups as the tachypnea, dyspnea and wheeze were associated with the higher viral load. These results were in agreement with Kim et al., (2011). We found that the more severe lower respiratory tract symptoms in our patients were associated with high $\mathrm{HBoV}$ virus load that was in agreement with Jiang et al., (2016).

Also, we found that the longer hospitalization period was accompanied with high $\mathrm{HBoV}$ viral load patients and that was in agreement with Deng et al., (2012).These results suggest that $\mathrm{HBoV}$ is a significant pathogen in young children with ALRI that was underestimated in our region. We detected three NPA samples with $\mathrm{HBoV}$ positive PCR results that were accompanied by bacterial co-infection and were associated with low virus load that result was in agreement with Jiang et al., (2016) who reported that co-infection was 
more frequently found among patients with low virus load than those with high virus load suggesting $\mathrm{HBoV}$ as causative agent of ALRI, this results were in agreement with the studies of Brieu et al., (2008) and Kaida et al., (2010).

We estimated HBoV $\operatorname{IgM}$ as another diagnostic tool for diagnosis of $\mathrm{HBoV}$ causing ALRI and we found that there were13/ 123 (16\%) positive cases by ELISA, these results were in agreement with previous results of $\operatorname{IgM}$ detection in children with HBoV in the studies by Zaghloul (2011) and Söderlund-Venermo et al., (2009) that were $18 \%, 19 \%$ respectively.

There were 16 positive IgM serum samples among 19HBoV DNA-positive patients (84.2\%) diagnosed by real-time PCR, which is highly sensitive technique. This study result was in agreement with that of Zaghloul (2011). However, our results were higher than that of Lindner et al., (2008) who detected
IgM against $\mathrm{HBoV}$ by ELISA in $(42 \%)$ of sera samples obtained from $\mathrm{HBoV}$ DNApositive children this difference may be due to different PCR technique used.

There was significant association between high viral load and positive serology that probably indicate active $\mathrm{HBoV}$ infection; there were $13 \operatorname{IgM}$-positive serum samples of patients who had high viral load among 16 IgM-positive serums. The three negative serological results had low viral load, this result was in agreement with Allander et al., (2007) who reported that seropositive cases mainly showed high viral load in nasopharyngeal aspirate. As regards to sensitivity, specificity, positive predictive value and negative predictive value of ELISA were $84.2 \%, 100 \%, 100 \%$ and $97.2 \%$,our results are near to values recorded previously by Lindner et al., (2008) and Zaghloul (2011).

Table.1 Demographic characteristics of patients with ALRT

\begin{tabular}{|l|l|}
\hline \multicolumn{1}{|c|}{ Patients characteristics } & $(\mathrm{n}=123)$ \\
\hline *Sex: & $97(78.86 \%)$ \\
Male & $26(21.14 \%)$ \\
Female & $37(7-59)$ \\
\hline${ }^{\#}$ Age, (months) & $7(1-13)$ \\
\hline Duration of symptoms before admission (days) & $4.5(1-9)$ \\
\hline Duration of hospitalization stay (days) &
\end{tabular}

Data are represented as median (range), mean $^{\#}$ or No $(\%)^{*}$

Table.2 Diagnostic efficiency HBo V IgM antibodies assay for detection of bocavirus

\begin{tabular}{|c|c|c|c|c|c|c|}
\hline & \multicolumn{2}{|c|}{ Real- time PCR } & \multirow{2}{*}{$\begin{array}{c}\text { Sensitivity } \\
(\%)\end{array}$} & \multirow{2}{*}{$\begin{array}{c}\text { Specificity } \\
(\%)\end{array}$} & \multirow{2}{*}{$\begin{array}{c}\mathrm{PPV} \\
(\%)\end{array}$} & \multirow{2}{*}{$\begin{array}{c}\text { NPV } \\
(\%)\end{array}$} \\
\hline HBoV IgM assay & Positive & Negative & & & & \\
\hline Positive & 16 & 0 & \multirow[t]{2}{*}{$84.2 \%$} & \multirow[t]{2}{*}{$100 \%$} & \multirow[t]{2}{*}{$100 \%$} & \multirow[t]{2}{*}{$97.2 \%$} \\
\hline Negative & 3 & 104 & & & & \\
\hline
\end{tabular}

$\mathrm{PPV}=$ positive predictive value, $\mathrm{NPV}=$ negative predictive value 
Table.3 Clinical characteristics and serology of children infected by human bocavirus (HBoV) with high virus load and low virus load

\begin{tabular}{|l|c|c|c|}
\hline \multicolumn{1}{|c|}{ Parameters } & $\begin{array}{c}\text { High Viral } \\
\text { Load } \\
(\mathrm{n}=13)\end{array}$ & $\begin{array}{c}\text { Low Viral } \\
\text { Load } \\
(\mathrm{n}=6)\end{array}$ & P value \\
\hline Fever & $9(69.2 \%)$ & $2(33.33 \%)$ & 0.319 \\
\hline Cough & $9(69.2 \%)$ & $1(16.7 \%)$ & 0.058 \\
\hline Wheezing & $12(92.3 \%)$ & $2(33.33 \%)$ & $0.017^{*}$ \\
\hline Tachycardia & $10(76.9 \%)$ & $1(16.7 \%)$ & 0.041 \\
\hline Tachypnea & $9(69.2 \%)$ & $1(16.7 \%)$ & 0.058 \\
\hline Dyspnea & $2(15.4 \%)$ & $4(66.7 \%)$ & $0.046^{*}$ \\
\hline Rhinorrhea & $9(69.2 \%)$ & $2(33.33 \%)$ & 0.319 \\
\hline Vomiting/diarrhea & $4(30.7 \%)$ & $1(16.7 \%)$ & 0.631 \\
\hline \#Duration of hospitalization stay (days) & $5(4-9)$ & $3(2-5)$ & $0.002^{*}$ \\
\hline HBo V IgM antibodies +ve & $13(100 \%)$ & $3(50 \%)$ & $0.02^{*}$ \\
\hline
\end{tabular}

(Data are represented as No (\%) or median (range) \#, * Significant value)

Fig.1 The Age distribution of patients with bocavirus infection

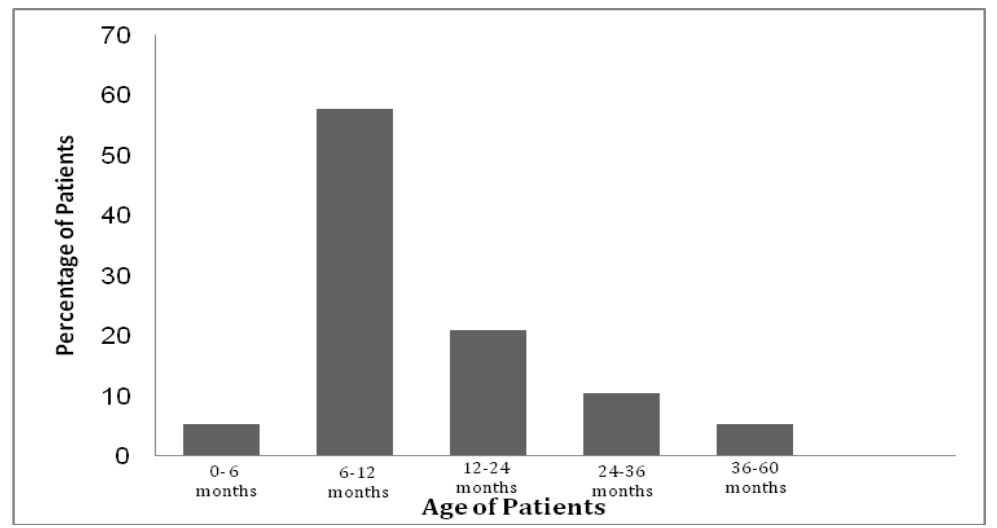

Fig.2 Seasonal distribution of human bocavirus infection during the study period among $2015-2016$

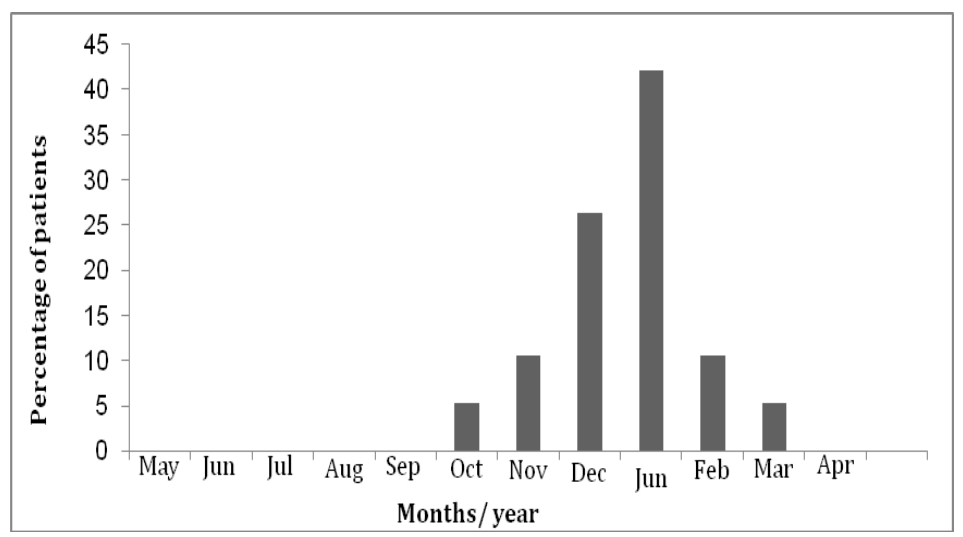


In conclusion, human bocavirus is an important cause of ALRI in young children less than five years; its incidence is highest in winter months. We used PCR and ELISA for the diagnosis of this virus, there was a high significant association between both methods that can confirm its role in ALRI and suggest active $\mathrm{HBoV}$ infection. There was an association between disease severity and $\mathrm{HBoV}$ viral load that is considered to be another clue for the role of $\mathrm{HBoV}$ as a causative agent of ALRI in young children less than five years. Wheezing and dyspnea were the most common clinical symptoms accompanied with high viral load; there presence may alert the pediatrician to investigate the presence of $\mathrm{HBoV}$ as a cause of ALRI. The high sensitivity and specificity of $\mathrm{HBoV}$ IgM detection by ELISA in comparison to real-time PCR is encouraging to recommend the usage of this easy non-sophisticated technique for diagnosis of $\mathrm{HBoV}$ infection in a wider scale.

An important limitation of this study was the relatively small number ALRI cases encountered during the time of the study, further larger study with the investigation of the association of $\mathrm{HBoV}$ with other respiratory viruses causing ALRI is recommended. To the best of our knowledge, this is the first study of the role of $\mathrm{HBoV}$ infection in ALRTI in children conducted in El Sharkia governorate, Egypt.

\section{References}

Abdel-Moneim, A.S., Kamel, M.M., Al-Ghamdi, A.S., Al-Malky, M.I., 2013. Detection of bocavirus in children suffering from acute respiratory tract infections in Saudi Arabia. PLoS One, 8, e55500.

Abdel-Moneim, A.S., Kamel, M.M., Hamed, D.H., Hassan, S.S., Soliman, M.S., AlQuraishy, S.A., El Kholy, A.A. 2016. A novel primer set for improved direct gene sequencing of human bocavirus genotype-1 from clinical samples. J. Virol. Methods, 228: 108-113.

Allander, T., Jartti, T., Gupta, S., Niesters, H.G., Lehtinen, P., Osterback, R., et al., 2007. Human bocavirus and acute wheezing in children. Clin. Infect. Dis., 44: 904-910.

Allander, T., Tammi, M.T., Eriksson, M., Bjerkner, A., Tiveljung-Lindell, A. and
Andersson, B. 2005. Cloning of a human parvovirus by molecular screening of respiratory tract samples. Proc. Natl. Acad. Sci. USA, 102: 12891-12896.

Al-Rousan, H.O., Meqdam, M.M., Alkhateeb, A., Al-Shorman, A., Qaisy, L.M., et al., 2011. Human Bocavirus in Jordan: Prevalence and Clinical Symptoms in Hospitalised Pediatric Patients and Molecular virus Characterization. Singapore Med. J., 52 (5): 365- 369.

Arthur, J.L., Higgins, G.D., Davidson, G.P., Givney, R.C. and Ratcliff, R.M. 2009. A novel bocavirus associated with acute gastroenteritis in Australian children. PLoS Pathog., 5: e1000391.

Brieu, N., Guyon, G., Rodiere, M., Segondy, M. and Foulongne, V. 2008. Human bocavirus infection in children with respiratory tract disease. Pediatr. Infect. Dis. J., 27: 969973.

Bruning, A.H., Susi, P., Toivola, H., Christensen, A., Söderlund-Venermo, M., Hedman, K., Aatola, H., Zvirbliene, A. And Koskinen. J.O. 2106. Detection and monitoring of human bocavirus 1 infection by a new rapid antigen test. New Microbes New Infect., 11:17-19.

Choi, E.H., Lee, H.J., Kim, S.J., Eun, B.W., Kim, N.H., Lee, J.A., Lee, J.H., Song, E.K., Kim, S.H., Park, J.Y. and Sung, J.Y. 2006. The association of newly identified respiratory viruses with lower respiratory tract infections in Korean children, 2000-2005. Clin. Infect. Dis., 43(5): 585-592.

Chow, B.D. and Espe, R.F.P. 2009. The human Boca viruses: a review and discussion of their role in infection. Clin. Lab. Med., 29(4): 695-713.

Deng, Y., Gu, X., Zhao, X., Luo, J., Luo, Z., Wang, L., Fu, Z., Yang, X. and Liu, E. 2012. High viral load of human bocavirus correlates with duration of wheezing in children with severe lower respiratory tract infection. PLoS One, 7(3): e34353. Doi: 10.137.

Dunn, J.J. and Miller, M.B. 2014. Emerging respiratory viruses other than influenza. Clin. Lab. Med., 34:409-430.

Ghietto, L.M., Cámara, A., Cámara, J. and Adamo, M.P. 2012. High frequency of 
human bocavirus 1 DNA in infants and adults with lower acute respiratory infection. J. Med. Microbiol., 61: 548-551. Doi: 10.1099/jmm.0.035600-0.

Guido, M., Zizza, A, Bredl, S., Lindner, J., De Donno, A., Quattrocchi, M., Grima, P., Modrow, S. 2012. Seroepidemiology of human bocavirus in Apulia, Italy. Clin. Microbiol. Infect., 18(4): E74-76.

Jiang, W., Yin, F., Zhou, W., Yan, Y. and Ji, W. 2016. Clinical significance of different virus load of human bocavirus in patients with lower respiratory tract infection. Sci. Rep., 6: 20246 doi: 10.1038/srep20246.

Kaida, A., Kubo, H., Takakura, K. and Iritani, N. 2010. Detection and quantitative analysis of human bocavirus associated with respiratory tract infection in Osaka City, Japan. Microbiol. Immunol., 54: 276-281.

Kapoor, A., Slikas, E., Simmonds, P., Chieochansin, T., Naeem, A., Shaukat, S., et al., 2009. A newly identified bocavirus species in human stool. J. Infect. Dis., 199:196-200. Available from http://dx.doi.org/10.1086/595831.

Kim, J.S, Lim, C.S., Kim, Y.K., Lee, K.N. and Lee, C.K. 2011 Human bocavirus in patients with respiratory tract infection. Korean J. Lab. Med., 31: 179-184.

Lindner, J., Karalar, L., Zehentmeier, S., Plentz, A.S., Pfister, H., Struff, W., et al 2008. Humoral immune response against human bocavirus VP2 virus-like particles. Viral Immunol., 21:443-449.

Mackay, I.M. 2004. Real-time PCR in the microbiology laboratory. Clin. Microbiol. Infect., 10: 190-212.

Martin, E.T., Fairchok, M.P., Kuypers, J., Magaret, A., Zerr, D.M., Wald, A. and Englund, J.A. 2010. Frequent and prolonged shedding of bocavirus in young children attending daycare. J. Infect. Dis., 201: 1625-1632.
Neske, F., Blessing, K., Tollmann, F., Schubert, J., Rethwilm, A., Kreth, H.W. and Weissbrich, B. 2012. Real-time PCR for diagnosis of human bocavirus infections and phylogenetic analysis. J. Clin. Microbiol., $\quad$ 45(7): 2116-2122. 1/journal.pone.0034353. Epub 2012 Mar 30.

Pavia, A.T. 2011. Viral infections of the lower respiratory tract: old viruses, new viruses, and the role of diagnosis. Clin. Infect. Dis., 52: S284-289 (Suppl 4).

Silva, A.K., de Mello, W.A., dos Santos, M.C. and de Sousa, R.C.M. 2010. Occurrence of Human Bocavirus Associated with Acute Respiratory Infections. Revista PanAmazônica de Saúde, 1(1): 87-92.

Söderlund-Venermo, M., Lahtinen, A., Jartti, T., Hedman, L., Kemppainen, K., Lehtinen, P., Allander, T., Ruuskanen, O. and Hedman, K. 2009. Clinical assessment and improved diagnosis of bocavirus-induced wheezing in children, Finland. Emerg. Infect. Dis., 15(9): 1423-1430.

Symekher, S.M.L., Gachara, G., James Maylor Simwa. J.M., et al., 2013. Human Bocavirus Infection in Children with Acute Respiratory Infection in Nairobi, Kenya Open J. Med. Microbiol., 3: 234-238.

Weissbrich, B., Neske, F., Schubert, J., Tollmann, F., Blath, K., Blessing, K. and Kreth, H.W. 2006. Frequent detection of Bocavirus DNA in German children with respiratory tract infections. BMC Infect. Dis., 6:109.

World Health Organization. 2009. Acute Respiratory Infections (Update September 2009). Dis. Burden.

Zaghloul, M.Z. 2011. Human bocavirus (HBoV) in children with respiratory tract infection by enzyme linked immunosorbent assay (ELISA) and qualitative polymerase chain reaction (PCR). Virol. J., 19(8): 239. Doi: 10.1186/1743-422X-8-239.

\section{How to cite this article:}

Ghada E. Amr, Dina M. Atef and Rabab Elbehedy. 2017. Detection of Human Bocavirus in Egyptian Children Suffering from Acute Lower Respiratory Tract Infection. Int.J.Curr.Microbiol.App.Sci. 6(2): 809-816. doi: http://dx.doi.org/10.20546/ijcmas.2017.602.090 